\title{
The Relationship of The Roles Of Both Civil And Private Society Towards The Indonesian Government That Practises Desentralised Democracy To Achieve Good Governance
}

\author{
Dadan Hidayatulloh \\ Department of Government Science \\ Padjadjaran University, Bandung, Indonesia \\ Utang Suwaryo \\ Department of Government Science \\ Padjadjaran University, Bandung, Indonesia \\ Affan Sulaeman \\ Department of Government Science \\ Padjadjaran University, Bandung, Indonesia \\ Nandang Alamsah Deliarnoor \\ Department of Government Science \\ Padjadjaran University, Bandung, Indonesia
}

\begin{abstract}
In a democratic country, civil society will develop and grow strongly. The state as an integration of political power, is the main organization of political power. Also, the state is a tool of society that has the power to regulate human relations in society and regulate the symptoms in society. Good governance can also be interpreted as a synergic and constructive relationship between the state, the private and the civil society. This study aims to find out and understand how is the relationship of the roles of both civil and private society in order to achieve good governance. In this research applied the civil society, state theory, the concept of good governance, and the concept of decentralization theory. The results that the relationship of the roles, both civil and private society can be seen through building democratic governance through the role of civil society, social and political participation in decentralization. Local governments in Indonesia, through a decentralized system, have enabled the rapid development of democracy. Thus, democratic governance depends on how much civic engagements are.
\end{abstract}

Keywords: decentralization, democracy, good governance.

\section{INTRODUCTION}

Democracy and civil society are like two sides of a coin, both are co-existence. With a strong civil society, democracy will work well (Putnam, 1993). In a democratic country, civil society will develop and grow strongly. Nurcholish Madjid (1999) made a quite interesting metaphor, civil society is a home of democratic nurseries so that democracy is not only reflected in free and democratic elections, but also requires nurseries namely civil society.

Larry Diamond (1994) stated that civil society contributed significantly to the growth of democracy. First, civil society provides facilities for political, economic, cultural and moral resources to maintain and monitor the balance of the state. Independent associations and free 
media provide the basis for restrictions on state power through public control. Second, diversity in civil society with various interests, if organized and managed properly, can be an important basis for democratic competition. Third, it will enrich the role of political parties in terms of political participation, increase political effectiveness and increase awareness of citizenship. Fourth, participate to maintain the stability of the state. Meaning that civil society and be able to maintain its independence, which means secretly reducing the role of the state. Fifth, as a forum for the selection and birth of new political leaders. Sixth, obstructing the dominance of authoritarian regimes.

Admittedly, the concept of civil society is understood from different perspectives and it is a dynamic development in accordance with the context, setting, ideology and interests of each subject (INCIS, 2002). In the Hegelian approach, the emphasis is more on the importance of the middle class and its empowerment, especially in the economic sector, for the development of a strong civil society. Meanwhile in the Gramscian perspective the strengthening of civil society as a tool to deal with the ideological hegemony of the state. Civil society is a place where organic intellectuals can become strong whose aim is to support efforts to resist state hegemony. In Tocquevellian's approach, the strengthening of civil society places more emphasis on strengthening independent organizations and associations in society and inciting civic culture to build the spirit of democracy.

Apart from the various approaches in understanding civil society, it seems relevant to put forward the definition of civil society according to Alfred Stepan (1988) below:

... arena where manifold social movement (such as neighborhood associations, women's groups, religious groupings, and intellectual currents) and civic organization from all classes (such as lawyers, journalist, trade union, and enterpreneurs) attempt to constitute themselves in an ensemble of arrangements so that they can express themselves and advance their interest.

Moreover, Stepan explicitly implies that civil society is not just an arena outside the state that seeks to articulate their interests, but also there is a horizontal awareness of community groups to gather themselves in associations and voluntary organizations to cooperate in a frame of order (ensemble of arrangement) which also stated by the US. Hikam (1996), that civil society is an organized area of social life and characterized like voluntary, self-supporting, high independence dealing with the state, and high attachment to legal norms or legal values that are followed by its citizens.

The state as an integration of political power, is the main organization of political power. Also, the state is a tool of society that has the power to regulate human relations in society and regulate the symptoms in society. The state is an organization which in a region can force its authority legally against all other power groups and who can determine the goals of that shared life. The state describes the existence of a power structure that monopolizes the use of legitimate physical coercion against groups of people who live in areas with clear boundaries. So, it can be said that the State is a grouping of people on the basis of the similarity of the power structure that governs it. The state has two tasks, namely:

1. Control and regulate the symptoms of asocial power, which are conflicting with one another, so as not to become a dangerous antagonism.

2. Organizing and integrating human activities and groups towards achieving the goals of the whole community.

The state according to Roger H. Soltau, is an agency or authority authority that regulates or controls common problems, on behalf of the community. The state (Harold J. Laski), is a society 
that is integrated because it has a force that is coercive and which is legally greater than individuals or groups as part of that society. The State (Max Weber), is a society that has a monopoly in the use of legitimate physical violence in a region. The State (Robert M. Mac Iver), is an association that organizes control within a community in a region based on a legal system organized by a government which is given the force of force (Budiarjo, 2003: 39).

This view is essentially a citizen recognition of the power and power of the State which must be accepted as a necessity. The recognition and/or the fact that the State has almost absolute power and power to impose the will has led to a struggle that continues to the present which in essence is how citizens must accept the consequences of power as well as how that power must be controlled not to be arbitrary. One of the most important functions in state and political science is to open and unravel the problems that are related and related to the power and power of the State, between the authorities and the people (Ranadireksa, 2007: 25).

Furthermore, there are three pillars of governance, namely the government, the private sector and the community. Good governance as a new paradigm of public administration emphasizes the existence of collaboration in equality and balance between governments, private society and civil society. Thus, good governance can also be interpreted as a synergic and constructive relationship between the state, the private sector and the community in the governmental administration. This was also conveyed by Bob Sugeng Hadiwinata that the basic assumptions of good governance must create synergies between government sectors (providing rules and policies), the business sector (driving the economy), and the civil society sector, meaning selfhelp activities to develop economic productivity, effectiveness and efficiency (Pandji Santosa, 2008: 131).

In general there are several characteristics inherent in good governance practices. First, the practice of good governance must provide space for parties outside the government to play an optimal role so as to enable synergy between them. Second, the practice of good governance have values that make the government and the private sector more effective in working to realize people's welfare. Values such as efficiency, fairness, and responsiveness are important values. Third, the practice of good governance is the practice of governance that is clean and free of corruption and oriented to the public interest. Therefore the practice of government is considered good if it is able to comply transparency, law enforcement, and public accountability.

Practically, there are some basic principles as a condition for the creation of good governance (Santosa Pandji, 2008: 131) are as follows:
1. Participatory
2. Rule of law
3. Transparency
4. Responsiveness
5. Consensus
6. Equality of rights
7. Effectiveness and Efficiency
8. Accountability

However, the implementation is faced with obstacles, among others, is the lack of knowledge and skills of the people in aggregating and articulating their political aspirations to be channeled through legitimate, constitutional and civilized political procedures and mechanisms. Such conditions can be understood as the initial process of decratisation. A 
democracy will not be realized without an awareness of the society as the subject of democracy. Public unconsciousness will lead them to be guided into political attitudes that transform them into masses who no longer understand political choices. Depotism then occurred due to the corruption of public spirit which caused civil society to lose direction (Keane, 1988).

Ramlan Surbakti explained that the State at the individual level is a group of individuals who have a number of authorities including drafting and implementing decisions/policies of all parties in a particular region. Associated with Indonesia which has a presidential government system, led by a president. President together with the government (at the institutional level) have power in order to manage everything, both society, nature and even infrastructure in Indonesia. In the reform era, a very strong state in the Soeharto regime could not be maintained anymore. In the era of transition, the State did not seem to continue to maintain its dominance and hegemony towards society. On the contrary, what happens is the relatively strong position of the people towards the State. The strong position of the community is reflected in their courage to carry out intense resistance and control of the State.

Reformation has shifted pendulum thus swings towards autonomy as stipulated in Law No. 22 Year 1999, including changes to article 18 of the Indonesian Constitution Year 1945 into a new provision. In practice, there are signs of pendulum swinging not just to seek balance but to move the balance to become an all-round region, all autonomy. Autonomy is a balancing and balancing instrument and balances the tendency to be centered and regional. Only then, autonomy will be an instrument of prosperity and peace for the whole life of the community, in a nation and in a state.

Furthermore, in the process of democratization, good governance often inspires activists to create a government that provides broad spaces of participation for actors and institutions outside the government so that there is a balanced and complementary division of roles and powers between the state, civil society, market mechanisms to enable checks and balances and also produce good synergies in realizing shared prosperity.

Therefore, in this study, the author will discuss how is the relationship of the roles between civil and private society towards the Indonesian government that practises desentralised democracy to achieve good governance.

\section{RESEARCH METHODS}

The method applied in this research is descriptive analysis method. Descriptive method is used to describe problems or obstacles and also point toward causal relationship of the roles both civil and private society, while analysis to analyze and to measure the relationship of the roles both civil and private society. Descriptive analysis method in this research used the regulation regarding regional autonomy as legal basis to describe, analyze and to explain how the relationship of the roles for both society created. The purpose of this study is find out and understand the relationship between the role of civil dan private society towards the Indonesian government in order to achieve good governance.

\section{RESEARCH RESULT AND DISCUSSION \\ Building Democratic Governance Through The Role of Civil Society}

In the relationship between the community and the state, civil society has three functions namely, first, as complementary where elements of civil society have activities to advance welfare to complement the role of the state as a public service. Second, as a subtitutor. Civil society circles carry out a series of activities that the state has not or has not done in relation to 
institutions that serve the interests of the wider community. And third, as a counter-state power or counterbalancing the state or counterve ground forces. Civil society groups carry out advocacy, mentoring, ligitation, even opposition practices to balance the hegemonic power of the state or at least become alternative discourses outside the state bureaucratic apparatus.

The above functions presuppose different points of press on the implementation of the ideas of civil society, between the socio-cultural domain or the political sphere. Iwan Gardono (2001), argues that civil society which emphasizes on socio-cultural aspects can be horizontal, usually closely related to civility or existence and fraternity. The indigenization of the concept of civil society is carried out in order to attract relevance to the societal context. Whereas civil society in the vertical connotation refers more to the political dimension, so that it is closer to the aspect of the citizen and liberty. The difference in press points has implications for diverse meanings, or at least various terms to refer to civil society.

By combining horizontally and vertically, the complementary functions, subtitles, and countervailing forces become an inseparable entity. Perhaps the problem lies in how civil society in various sectors and areas of concern of the activities they undertake can share their role towards creating community-based democratization.

Democratic governance is a system of government based on popular sovereignty. Democratic governance depends on how much civic engagement citizens are. There is a process of involving the community in monitoring government performance. Political power spreads in society and national politics is the result of fighting in society. The involvement of citizens in potential associations that fosters openness, trust, tolerance and other positive attitudes then becomes important in the building of national politics (Putnam, 1993). Thus, democracy does not consumbed by the elite only, but experiences reexamination transparently and continuously in public, not only during the election period.

In the context of the growth of elements of democracy, we cannot escape from the basic components of democracy, namely the active participation of civil society. This means that it is necessary to restore people's rights as stakeholders in decision making so as to show the link between democracy, autonomy and participation.

\section{Social Partisipation in Decentralization}

Social participation and trust are the parameters of civic engagement and are one side of the currency that cannot be separated from political engagement. If political engagement concerns the involvement and psychological connection of citizens with political and governmental affairs, the civic engagement involves the involvement of citizens in voluntary social activities and trust among the same citizens.

The study of civil society in relation to democracy talks about a series of political participation in social relations that is carried out voluntarily. Thus, democracy presupposes a mechanism of active community involvement. In a democratic government, its existence is guaranteed. Political participation, generally interpreted as voluntary action to change the state or public policy (Barnes, Kaas, 1978). Political participation is divided into two, namely political participation itself and social participation.

Social participation is defined as citizen involvement in the social life or civic community. In other words, civic engagement in social groups becomes a part of social participation. The social group itself is characterized by two activities. First, the intensity of participation in 
solving social problems between citizens. This means that fellow citizens have concrete concerns and actions to solve social problems around them by taking collective action. This is possible if each citizen wants to open himself up to be involved in communicating and associating with other citizens. The more intensively the association between citizens occurs, the chance of positive collective activities can be opened wider. The involvement of citizens in community communities or social groups clearly reinforces social networks between citizens. If, the social network opens up great possibilities for public problem solving. Conversely, if the social network is depleted, which is characterized by a strong selfish attitude and is reluctant to get involved in the community.

Second, social groups are determined by intensity in forming social organizations. This second social activity clearly requires skills or skills, the aspects of leadership (leadership), having basic knowledge of organization and know how to run it, have the terms or basic elements of the organization and others. How far an intensity of citizens forms groups or social organizations is usually determined by how strong social networks are formed and how much involvement in the community to talk about public problems is established among fellow citizens.

One of the things that shows a change in this reform era can also be seen through Law No. 22 Year 1999 concerning Regional Autonomy. In particular Law No. 22 Year 1999 has repeatedly experienced changes for improvement. The study of the contents of the Act attracted the attention of many parties, and often opened debate. An example is about how much the Central Government delegates its authority to autonomous regions as known as decentralization. Meanwhile, referring to Law No. 22 Year 1999 concerning the local government, it is stated that regional autonomy emphasizes the principles of democracy, community participation, equity and justice, and considers the potential and diversity of the region.

Whereas the characteristic of Law No. 22 Year 1999 is the first of democracy and democratization, namely giving full authority to the people in the regions through the Regional People's Representative Council (DPRD) both in the provinces and in the Districts and Cities. There is no more interference from the central government, who will be the Governor, Mayor, is fully handed over to the local community to determine it. Then regarding the legalization process there were striking changes. All regional regulations issued by the Provincial, Regency and City Governments no longer have to be submitted by the Central Government. This increases the intensity of citizen participation in solving social problems around it relatively does not require expertise and management and the intensity is greater than the type of activity of the first social group. The more often people interact about social problems to the government, the greater the chances of solving social problems.

Moreover, to the ability of the community to solve social problems, the formation based on public awareness to gather and organize is also one indicator in terms of the community want to organize themselves collectively. In the democratization of Asian countries, notably South Korea, Philippines, Thailand, and Indonesia, the role of elites' was pre-eminent, but would not have been achieved without the active participation of civil society organizations. They generated political pressure for reform, leading to the liberalizing of political systems.

When Indonesia entered a new phase, namely the reform era the freedom to have opinion began to grow. The era of the authoritarian regime began to disappear, replaced by democracy. Democracy in all aspects included the freedom of speech are permitted, as well as the freedom to criticize the government when made a mistakes. Media industry and the press were growing rapidly in Indonesia, even it appears everywhere. 
Civil society involves private citizens acting collectively to make demands to the state or to express in the public sphere. Civil society may encompass a wide range of organizations concerned with public matters. They include civic, issue-oriented, religious, and educational interest groups or associations, also non-governmental organizations or NGOs which have grown from only around 10,000 in 1996 to around 70,000 in 2000. This phenomenon is similar to what has happened in various other countries, where the number of NGOs has increased sharply. It is not surprising, therefore, that NGOs have become the third Sector, namely the public sector that prioritizes social or personal care.

Countries that face the world economic crisis and the depletion of resources, NGOs can offer services such as help the government in solving rural community development problems by mobilizing local resources to be used productively. In addition, NGOs also have the potential to build an international network that can be mobilized to support their struggle at home. Thus, NGOs are an important factor in the development process. (Mas'oed, 2003).

The involvement of the private sector in optimizing public services is very supportive in achieving the big goal of Good Governance. In the concept of Good Governance, the role of the community and the private sector becomes very important because of the development paradigm changes by reviewing the role of government in development, which initially served as regulators and market players, becoming how to create a conducive climate and make infrastructure investments that support the business world. This can be realized if the community and the private sector themselves have adequate capabilities. It can then be understood that the government, especially in third countries, now no longer dominates or monopolizes the role of providing quality public services.

\section{Political Partisipation in Democracy}

Democracy requires active participation from ordinary people to convey their aspirations or interests, and participate in deciding public policies that must be taken by the government. Participation determines who must be a public official, what decisions must be taken and implemented by the government, and how the implementation of the mandate of the people is controlled so that irregularities can be suppressed, if not completely eliminated. Political participation is defined as an act not the belief or attitude of an ordinary citizen, not a political elite, to influence decisions relating to the public interest, not a particular religious group, for example, and voluntarily, not forced (Islamic Research Report and Good Governance, 2002).

Political participation is closely related to how far democracy is applied in government. A country that has a stable democracy, usually the level of political participation of its citizens is very stable, not fluctuating. Authoritarian countries often use violence to suppress every initiative and participation of their citizens. Therefore, instead of the form and quantity of increased participation, what happens is that citizens have no freedom to be autonomous from the fingers of power and there is no participation at all in an authoritarian government. Countries that are pursuing a process of transition from authoritarianism to democratic democracy are preoccupied with the types and forms of participation that are very numerous, ranging from those that are constitutional to those that are destructive to public facilities.

The biggest proportion of people participating politically is through elections. Besides the election, the biggest proportion is social participation, followed by participation related to political parties and campaigns (attending party campaigns or party marches, wearing party signatures, distributing party leaflets, and helping parties), and the lowest proportion is participation in the form of protests (demonstrations, strikes, boycotts, and protests by 
damaging public facilities) carried out to support or reject decisions relating to the public interest, even protest considered as a form of participation that is relatively rare for citizens.

Election participation shows the extent of citizens conventional participation. Someone who voted in the election, in a simple way, showed a commitment to citizen participation. But people who do not use their right to vote in elections do not mean they have no concern for public problems. The election has been determined regularly whether four, five, or seven years, which is usually contained in the state constitution, even though the date of its implementation is definitely usually included in the stages of the election that has been mutually agreed and procedures and technical operations have been determined.

Therefore, someone who participated in the campaign proved a better level of concern than voting for elections because political participation was also determined by how much the level of participation of citizens. Participating in the campaign of political parties showed someone's curiosity towards the party program before he dropped his vote in the election event.

Through Law No. 22 of 1999, there is a huge opportunity for the strengthening of the people in the regions by strengthening the DPRD through the political rights of the people. Communities can participate in determining public policy. The people have the authority to participate in planning and determining where their area will be developed. Besides that the people can control both the Executive and the Legislature for the performance produced. Thus, it is expected that the Government in the Regions can be careful in running the wheels of government in the Region.

One of the main factors and subjects related who play a role in the realization of clean government and good governance is the bureaucracy, in its position and role which is so important in managing public policies and services, bureaucracy greatly determines the efficiency and quality of service to the community, as well as the effectiveness in implementing government and development. In order to achieve good governance, every element of both the government, private sector and civil society needs to first understand the basic thinking about the concept of bureaucracy and the concept of good governance so that there is no dualism in the vision that will worsen the course of bureaucratic reform towards good governance in Indonesia.

\section{CONCLUSION}

Civil society is not just an arena outside the state that seeks to articulate their interests, but also there is a horizontal awareness of community groups to gather themselves in associations and voluntary organizations to cooperate in ensemble of arrangements. Law No. 22 Year 1999 can be seen as a huge opportunity for the strengthening of the people in the regions by strengthening the Regional People's Representation Council. Communities can also participate in determining public policy. The people have the authority to participate in planning and determining where their area will be developed. Besides that the people can control both the Executive and the Legislature for the performance produced. Thus, it is expected that the Local Government can govern carefully. Local government through decentralization enabled the rapid development of democracy.

The relationship of the roles, both civil and private society can be seen in building democratic governance through the role of civil society, social and political participation in decentralization. Good governance can also be interpreted as a synergic and constructive relationship between the state, the private and the civil society. Thus, can only be achieved not only by how the democratic governance depends on how much civic engagement citizens are. 
There is also a process that involves the community in monitoring the performance of government. Political power spreads in society and national politics is the result of fighting in society. In countries that have to face the world economic crisis and the depletion of resources, NGOs can offer attractive services. NGOs also have the potential to build an international network that can be mobilized. Thus, NGOs are an important factor in the development process.

\section{References}

Budiarjo, Miriam. 2003. Dasar-Dasar Ilmu Politik. Jakarta: Gramedia Pustaka Utama.

Diamond, Larry. 1994. Rethinking Civil Society. Journal of Democracy 5.

Fakih, Mansour. 1996. Masyarakat Sipil untuk Transformasi Sosial: Pergolakan Ideologi LSM Indonesia. Yogyakarta: Pustaka Pelajar.

Gardono, Iwan. 2001. Wacana Civil Society di Indonesia. Dalam “Jurnal Masyarakat Sipil”, Nomor 9.

Hikam, Muhammad AS. 1996. Demokrasi dan Civil Society. Jakarta: LP3ES.

Inglehart, Ronald. 1999. The Renaissance of Political Culture. Journal American Political Science Review 82.

Laporan Penelitian Respons Pegawai Terhadap Pengembangan Etika Birokrasi di Lingkungan Pemerintah Propinsi DKI Jakarta. 2002. Jakarta: INCIS dan Bapinroh.

Launa. 2009. Buruh dan Kemiskinan. Dalam Jurnal Sosial Demokrasi, Vol.7 No.2 September-Desember 2009.

Madjid, Nurcholis. 1999. "Masyarakat Madani dan Investasi Demokrasi: Tantangan dan Kemungkinan”, dalam Ahmad Baso, Civil Society versus Masyarakat Madani: Arkeologi Pemikiran "Civil Society" dalam Islam Indonesia. Bandung: Pustaka Hidayah.

Mas'oed, Mochtar. 2003. Negara, Kapital, dan Demokrasi. Yogyakarta: Pustaka Pelajar.

Mujani, Saiful. 2001. Religious Democrats: Democratic culture and Muslim Participation in Post Suharto Era. Columbus: Ohio State University.

Poerwadarminta. 1987. Kamus Umum Bahasa Indonesia. Jakarta.

Putnam, Robert D. 1993. Making Democracy Work: Civic Traditions in Modern Italy. Princeton, NJ: Princenton University Press.

Ranadireksa, Hendarmin. 2007. Arsitektur Konstitusi Demokratik. Bandung: Fokus Media.

Santosa, Pandji. 2008. Administrasi Publik, Teori dan Aplikasi Good Governance. Bandung: Refika Aditama. Stepan, Alfred. 1998. Rethinking Military Politics: Brazil and the Southern Cone. Princeton University Press. Syadzily, Tb Ace Hasan dkk. 2003. Civil Society dan Demokrasi. Jakarta: INCIS. 